\title{
Ectoparasites from Feral Pigeons Affecting Humans
}

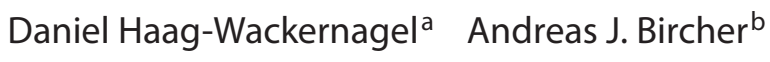 \\ ${ }^{a}$ Department of Biomedicine, Institute of Anatomy, University of Basel, and ${ }^{\mathrm{b}}$ Allergy Unit, Department of \\ Dermatology, University Hospital Basel, Basel, Switzerland
}

\section{Key Words}

Zoonosis - Zooanthroponosis ·

Ectoparasites, disinfestation $\cdot$ Feral pigeon Columba livia - Bedbug Cimex lectularius . Pigeon bug Cimex columbarius · Pigeon flea Ceratophyllus columbae $\cdot$ Chicken flea Ceratophyllus gallinae $\cdot$ Red mite Dermanyssus gallinae $\cdot$ Northern fowl mite Ornithonyssus sylviarum • Pigeon tick Argas reflexus

\begin{abstract}
Feral pigeons pose a considerable health risk to the human population. They are vectors of infectious diseases and source of antigens causing allergic diseases. Breeding and roosting sites of pigeons harbor parasites that may infest humans. In the present article, a concomitant parasitization of a young female with 3 different ectoparasites, the bedbug Cimex lectularius, the pigeon tick Argas reflexus and the red mite Dermanyssus gallinae, is reported. The parasites invaded the apartment from a balcony used as roost by feral pigeons and infested the patient continuously over a period of more than 2 months. To our knowledge this case presents the first record of a coincidental infestation of a single patient with several ectoparasite species deriving from feral pigeons. Additionally we report general symptoms in the patient probably caused by the high number of stings. Dermatologists
\end{abstract}

should be aware of the possibility of an infestation with ectoparasites deriving from feral pigeons. In a review we give an overview on the most important ectoparasites transmitted from feral pigeons to humans and their importance for the dermatologist. Copyright $\odot 2009$ S. Karger AG, Basel

\section{Introduction}

Feral pigeons (Columba livia Gmelin, 1789) are among the most successful avian settlers in our cities. They are distributed worldwide and live close to the human population. The average feral pigeon population is around 1 pigeon per $10-20$ city inhabitants $[1,2]$. The world population is therefore estimated to be between 165 and 330 million individuals. Feral pigeons bring pleasure to people who feed them, but the large food supplies provided by pigeon friends and food leftovers, together with the absence of enemies, allows the development of large populations that can cause various problems [3-5]. An individual feral pigeon produces around $12 \mathrm{~kg}$ of excrement each year [6], soiling buildings and public areas. Large quantities of droppings accumulate in particular in its roosting and breeding places. Pigeon feces provide ideal conditions for the growth of mould fungi that damage construction, as e.g. stone and concrete, leading to erosion of historic buildings and monuments [7, 8] The damage caused by an individual feral pigeon has been estimated to be EUR 23.733.5 per year [9]. In the USA, feral pigeons cause an estimated USD 1.1 billion per year in damages. These damage costs do not include the damages associated with their role as reservoirs and vectors for diseases [10].

Suitable nesting sites are rare in most cities, leading to intense competition and overcrowding at breeding sites which produces poor living conditions due to social stress, diseases and parasites $[1,3]$.

Feral pigeons can pose various health hazards to man and his domestic animals. In feral pigeon populations so far 109 different pathogenic agents that can infest humans have been recorded, but only 7 have in fact been transmitted to humans, causing a total of 230 reported infections $[11,12]$. These were Chlamydophila psittaci with 101 cases and 2 fatal courses, Histoplasma capsulatum with 91 cases, Cryptococcus neoformans with 11 cases and 2 fatal courses, Aspergillus sp. with 13 cases and 9 fatal courses, Candida sp. with 12 cases and Toxoplasma with 1 case [updated from 12]. 229 of 230 infections were transmitted by the airborne route and can therefore be prevented by hygienic precautions in most cases when handling pigeons and their excrements. Only 1 case has been described where the patient was infected

\section{KARGER}

Fax +4161306 1234 E-Mail karger@karger.ch www.karger.com
(C) 2009 S. Karger AG, Basel

$1018-8665 / 10 / 2201-0082 \$ 26.00 / 0$

Accessible online at: www.karger.com/drm
Prof. Daniel Haag-Wackernagel

Department of Biomedicine, University of Basel

Pestalozzistrasse 20

CH-4056 Basel (Switzerland)

Tel. +41 6126739 46, E-Mail daniel.haag@unibas.ch 
by the cutaneous route. An HIV-positive former intravenous drug addict presented with a primary cutaneous cryptococcosis after an injury inflicted by pigeons nesting in an abandoned house [13].

Exposure to pigeons and their effluents can cause 'pigeon breeder's lung', a hypersensitivity reaction causing allergic alveolitis provoked by inhaled pigeon antigens. To date a total of 9 cases, 1 with fatal outcome, have been reported due to feral pigeons [14-17].

Many wild-living species have a parasitic fauna comparable to the feral pigeons, but no other species lives as closely to humans. They use various building structures for roosting and breeding, and therefore their parasites and pathogens are at close distance to humans, presenting a serious health risk.

We report a case of concomitant infestation with Dermanyssus gallinae, Argas reflexus and Cimex lectularius due to feral pigeons using a balcony for roosting. To our knowledge, this is the first reported case where one individual has concurrently been attacked by 3 different ectoparasites deriving from feral pigeons. In a review we point out the importance of feral pigeons and their ectoparasites for dermatologists.

\section{Case Report}

A 26-year-old American female student had suffered from a cat dander allergy and from cat flea Ctenocephalides felis infestation in the past. On April 5, 2009 she moved into an apartment on the 4th floor of an old carelessly renovated apartment building, where the former tenant had fed a group of 8-10 feral pigeons on her balcony. The pigeons used the balcony as an overnight roost and most likely for breeding. The floor of the balcony was completely covered with a layer of feces and feathers of about $5 \mathrm{~cm}$ height that was removed by the former tenant before the patient moved into the apartment. Ten days later, she awoke 4-5 times with a 'burning feeling' on the legs. In the morning she first noticed an exanthema that consisted of hundreds of small itching papules on the legs, forearms, loin and abdomen. The next day she found high numbers of insects she later identified as bedbugs. The following night she suffered from general symptoms such as fatigue, weakness, dizziness, tachycardia and thoracic oppression and slept against her habit more than
$14 \mathrm{~h}$. The general symptoms disappeared on the next day. Two days later she presented to her general practitioner who diagnosed a 'rash' and a nodule with a central sting on the forearm and who prescribed fexofenadine. For the following 2 months she only noticed sporadic stings.

Preparing a lecture on the feral pigeon problem, she came across articles on hygienic problems deriving from feral pigeons $[11,12]$. By an internet search she identified insects she found on the floor, on a water bottle and near her clock radio as bedbugs C. lectularius which she disposed of by vacuum cleaning. Later, she clearly identified bedbugs from specimens of our parasite collection. In the morning she noted additional stings in a disseminated distribution that had occurred during the night. These stings were different from the stings of the first infestation as they occurred as larger linearly assorted urticarial and papular stings. During the night she found another 3 bedbugs C. lectularius beside the bed that she immediately disposed of by vacuum cleaning. In addition she discovered a hiding place of bedbugs in her clock radio, which by pushing a button could be forced to leave this only electric apparatus in the room. She then disposed of the clock radio including the bugs in a plastic bag.

Her 25-year-old partner who occasionally stayed overnight with her was also infested with red mites and presumably with bedbugs but not with pigeon ticks. He showed papules on the legs, abdomen, breast and general symptoms such as fatigue, weakness, dizziness, dyspnea, palpitations and heat waves that disappeared within 1 day. He did not consult a physician.

On the upper side of her mattress that lay directly on the floor, she detected pigeon ticks Argas reflexus that she also disposed of with a vacuum cleaner. She and her partner moved to the living room for sleeping to escape further stings and because of the fear of a reinfestation.

On April 27, a pest controller performed a disinfestation of the balcony and the apartment with dichlorvos, deltamethrin and pyrethrum. He confirmed the presence of pigeon ticks and red mites. On the floor and at the glazed door between the balcony and the bedroom, hundreds of red mites crawled about. This glazed door did not fit completely, which allowed parasites to enter the bedroom from the balcony. A final check was performed 1 week later.
Two weeks later, she applied to one of us (Haag-Wackernagel) for an interview concerning her lecture on feral pigeons and brought the parasites she had recovered from the vacuum cleaner. The parasitological determination confirmed pigeon ticks (fig. 1) and red mites (fig. 2). One tick $(9.3 \times 6.1 \mathrm{~mm})$ showed remains of blood and had bursted when aspirated, an unfed tick of $4.9 \times 3 \mathrm{~mm}$ was alive. Later, she found 8 additional dead pigeon ticks on her balcony, one of them engorged with blood. The red mites were partly engorged with blood which was visible from the dark-brown-colored intestine.

On her left forearm she had an excoriated nodule of $7 \mathrm{~mm}$ in diameter with a perifocal erythema (fig. 3). On the legs she still had small excoriated papules caused by the mite stings (fig. 4).

On May 16, she installed a bird net to prevent the pigeons from using the balcony as overnight roost. Nine weeks after the first infestation she still found red mites in the bedroom and living room. Every 3 days she used a pyrethrum spray around the balcony door to kill invading mites. Since the disinfestation by the pest controller, the number of stings had decreased but still occurred in lower numbers, preferentially on the legs.

On June 10, after more than 2 months of parasite attacks, we performed a detailed on-site search. On the balcony we found living pigeon ticks (fig. 5) and dead red mites in wall chinks and gaps of the glazed door. We found tick feces around holes and chinks of the wooden coverings and the walls as well as at the opened bathroom window where 2 feral pigeons were roosting. All other balconies and window ledges of the house including the neighboring houses were fouled with pigeon feces and on 2 balconies pigeon nests were present. The 46-day-old pigeon tick sting of the patient was still painful on palpation and showed a persistent inflammation (fig. 3).

As an ad hoc measure, we placed a glue barrier to test whether parasites still invaded the apartment. We advised the patient to contact her landlord to claim complete disinfestation and renovation including sealing of all gaps and chinks and a disinfestation or removal of the canopy covering the balcony.

Two weeks later, she brought 4 living pigeon ticks she had found on the balcony and the glue tapes placed in front of the glazed door. The 108-cm-long and 6-cmwide tape contained 60 red mites, con- 
1

Fig. 1. Pigeon ticks Argas reflexus found in the bedroom selected from the vacuum cleaner by the patient. The tick below is engorged with blood and burst when aspirated, the upper starving tick is intact.

Fig. 2. Red mites Dermanyssus gallinae, some engorged with blood (dark brown intestine).

Fig. 3. a 25-day-old sting of the pigeon tick Argas reflexus. b The same sting when 46 days old.

Fig. 4. Red mite stings on the knee of the patient.
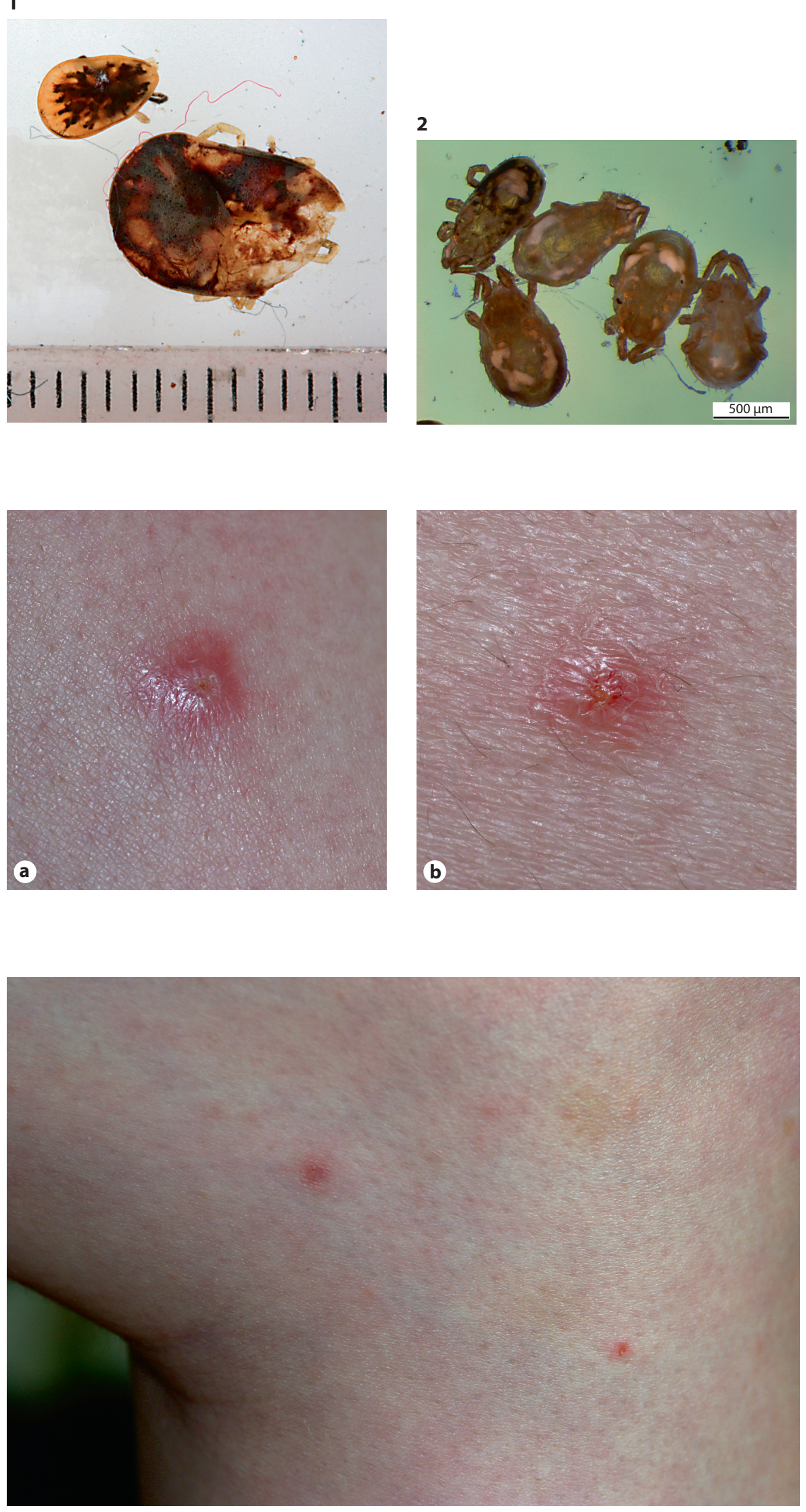
Fig. 5. Pigeon tick hiding in the chink of the junction of the floor and the wall (circle). The black spots are tick feces (arrows), a reliable sign for the presence of pigeon ticks.

firming a continued invasion from the balcony. The largest distance a mite covered from the edge before having been caught in the glue was $23 \mathrm{~mm}$. As a preventive measure she vacuum-cleaned daily to remove invading red mites and used an insecticide spray around the balcony door every 3 days. Since our on-site visit, she was not stung any more.

\section{Dermatologically Relevant Ectoparasites from Feral Pigeons}

Feral pigeons are a well-known source of zoonotic ectoparasites. We give here an overview on the most important ectoparasites and their clinical importance. Epidemiological studies of the parasitic fauna of feral pigeons revealed 17 ectoparasites from 6 orders known to potentially infest humans [18]. These ectoparasites, presented in table 1 , are possible candidates for human infestations. Of these ectoparasites, 8 have been reported to cause infestations in humans (table 2).

The Pigeon Bug Cimex columbarius and the Bedbug Cimex lectularius

C. lectularius, the common bedbug of man, is distributed throughout the temperate and tropical regions of the world

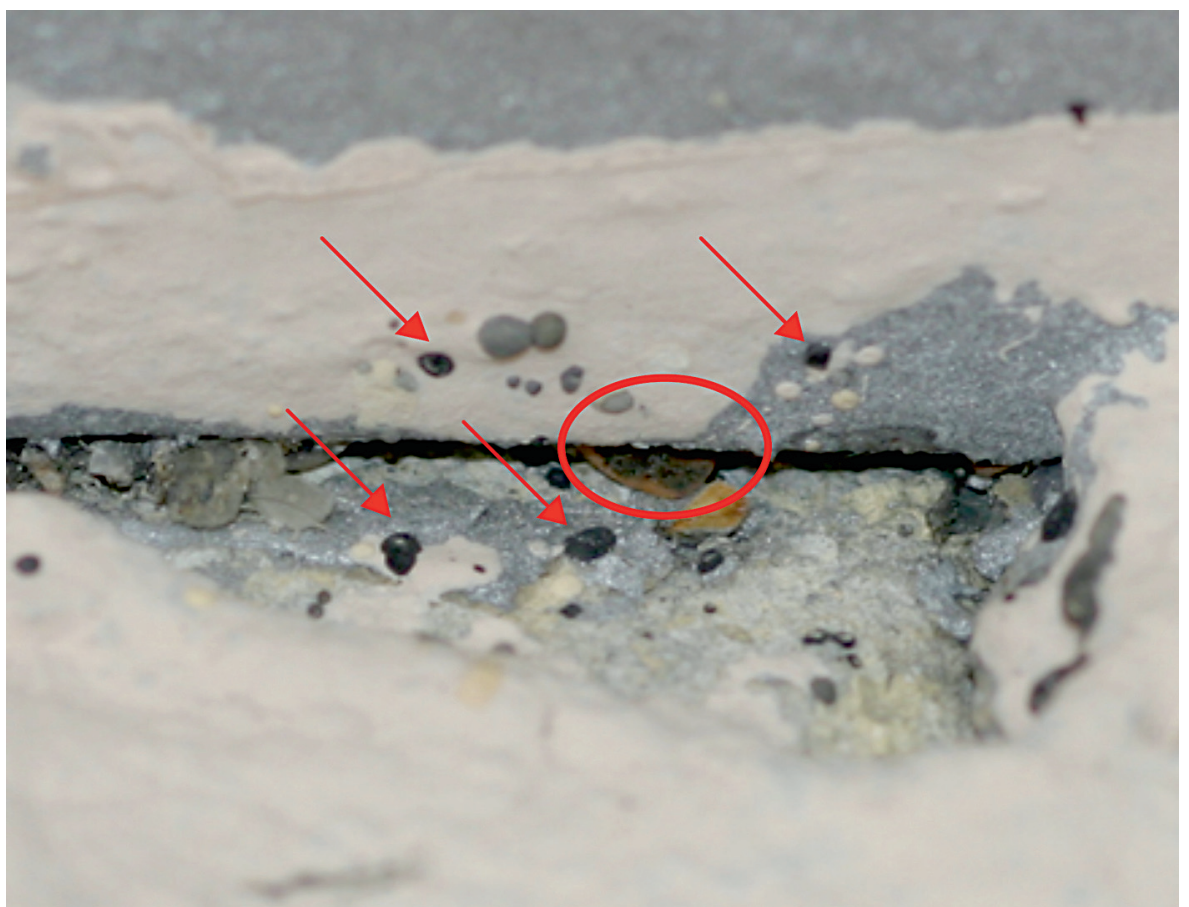

[19]. Beside man it parasitizes domestic mammals, bats and birds including pigeons. The common bug of pigeons is $\mathrm{Ci}$ mex columbarius (fig. 6) that is restricted to Northwestern Europe. C. lectularius and C. columbarius are closely related species and difficult to distinguish [20]. C. columbarius is smaller than C. lectularius and has a relatively short third antennal segment. The bedbug is almost oval, unfed 4-7 $\mathrm{mm}$ long and fed up to $9 \mathrm{~mm}$. Pigeon bugs are slightly smaller with $3.75-4.75 \mathrm{~mm}$. The integument is usually covered with short hairs or bristles. Furthermore both species can parasitize pigeons at the same time [21]. After a blood meal, the bugs may increase in length by $30-50 \%$ and in weight by $150-200 \%$. Adults are reddish brown in color, whereas immatures are much smaller and may be light yellow. They have a pyramidshaped head with prominent compound eyes, slender antennae, and a long proboscis tucked underneath the head and thorax. Bedbugs sense and seek warmth, a trait that helps them to locate warmblooded hosts. They generally avoid light, hide during the day and feed at night. Hiding places are usually within 1-2 m of suitable hosts and include seams in mattresses, crevices in box springs, backsides of headboards, spaces under baseboards or loose wallpapers, and even behind hanging pictures [22]. Adult bedbugs have a life span of 6-12 months and can survive up to a year without feeding. Starving periods normally lead to an extension of the lifetime of the parasite. The bedbug has a unique mode of copulation termed 'traumatic' insemination during which the male pierces the female's abdominal wall with his external genitalia and inseminates into her body cavity [23].

Most blood feeding occurs at night, particularly in the hours before dawn, on sleeping victims, but bedbugs may also feed during the day if conditions are favorable. All Cimex species have mouthparts that are modified for piercing and sucking. When near a prospective host, the bug moves toward the host and the tip of the feeding apparatus is brought into contact with the skin. Fine stylets are extruded and forced into the tissue, injecting an anticoagulant as well as pharmacologically active substances, and withdraw blood and liquefied epidermal tissue. Cutaneous reactions are induced by the injection of substances such as hyaluronidase, proteases and kinins [24]. Bites usually occur on exposed skin surfaces.

Reactions can range from localized urticaria to bullous reactions and to anaphylaxis in rare cases [24]. The usual response 
Table 1. Ectoparasites of the feral pigeon known as potentially infesting humans

\begin{tabular}{|c|c|c|}
\hline Order & Family and species & Incidence \\
\hline Heteroptera & $\begin{array}{l}\text { Cimicidae: Cimex lectularius, bedbug } \\
\text { Cimicidae: Cimex columbarius, pigeon bug } \\
\text { Reduviidae: Reduvius personatus, masked hunter } \\
\text { Reduviidae: Triatoma maculata, kissing bug } \\
\text { Anthocoridae: Lyctocoris campestris, debris bug }\end{array}$ & $\begin{array}{l}\text { occasional } \\
\text { occasional } \\
\text { very rare } \\
\text { very rare } \\
\text { very rare }\end{array}$ \\
\hline Brachycera (flies) & Hipposcidae: Pseudolyncha canariensis, hippoboscid fly, pigeon fly & very rare \\
\hline Psocoptera (booklice) & Psocodea: Liposcelis bostrychophila, booklouse & very rare \\
\hline Acari (mites) & $\begin{array}{l}\text { Dermanyssidae: Dermanyssus gallinae, red mite } \\
\text { Dermanyssidae: Ornithonyssus sylviarum (Liponyssus sylviarum), northern fowl mite } \\
\text { Glycophagidae: Glycophagus domesticus, house mite } \\
\text { Acaridae: Tyrophagus dimidiatus }\end{array}$ & $\begin{array}{l}\text { very common } \\
\text { very rare } \\
\text { very rare } \\
\text { very rare }\end{array}$ \\
\hline
\end{tabular}

Table 2. Ectoparasites transmitted from feral pigeons to humans

\begin{tabular}{lrc}
\hline Parasites & Reports & Patients \\
\hline Cimex lectularius, bedbug & 1 & $>2$ \\
Cimex columbarius, pigeon bug & 2 & $>6$ \\
Ceratophyllus columbae, pigeon flea & 7 & $>11$ \\
Dermanyssus gallinae, red mite & 29 & $>74$ \\
Ornithonyssus sylviarum, northern fowl mite & 1 & 3 \\
Argas reflexus, pigeon tick & 47 & $>274$ \\
Argas latus & 1 & $>2$ \\
Argas polonicus & 1 & $>2$ \\
\hline Total & 89 & $>374$ \\
\hline
\end{tabular}

Numbers of patients are indicated with '>' when the precise number was not communicated.

to a bedbug bite appears to be no reaction with a small punctum at the location of the bite. The most common reactions for which medical attention is sought are 2- to 5 -mm pruritic maculopapular, erythematous lesions [25] that resolve within a week. Some patients experience complex cutaneous reactions including pruritic wheals around a central punctum and papular urticaria at bite sites. Reinhardt et al. [26] could demonstrate that 18 of 19 persons showed a skin reaction after bedbug bites, but in most cases only after repeated exposure. With repeated exposure, the latency between bite and skin reactions decreased from approximately 10 days to a few seconds. Bullous rashes may occur subsequent to biting events days later [27]. In some cases these reactions evolve into pruritic papules or nodules that may become superinfected after scratching and persist for weeks. Secondary complications may

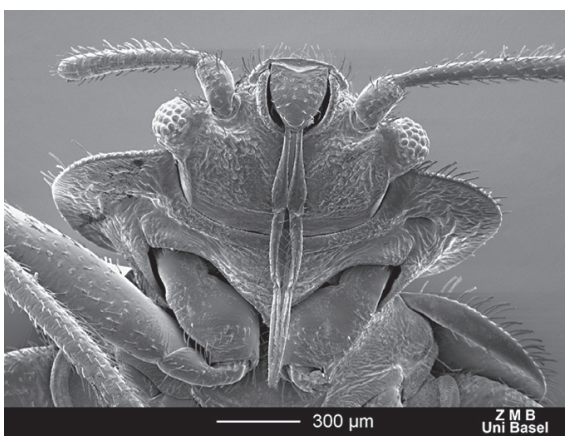

Fig. 6. Portrait of the pigeon bug Cimex columbarius, an ectoparasite specialized on pigeons, that can cause infestations in humans. The back-folded proboscis encases the fine stylets of the feeding apparatus.

result in folliculitis, cellulitis or eczematoid dermatitis. There are few studies of systemic reactions from bedbug bites, including asthma, generalized urticaria and anaphylaxis [22]. Treatment of common and complex cutaneous reactions is usually symptomatic with application of antipruritic agents or intermediate-potency corticosteroids; systemic reactions are treated as insect-induced anaphylaxis. Anxiety and lack of sleep may be associ- 
ated with infestations [24]. Transmission of more than 40 human diseases has been attributed to bedbugs, but there is little evidence that such transmission has ever occurred [22].

Minimal symptomatic treatment and good hygiene to prevent itching and secondary infections are usually sufficient in most cases. Topical steroid creams with or without systemic anti- $\mathrm{H}_{1}$ receptor antihistamines may be given in severer cases [24]. In the case of an infestation a thorough on-site inspection of crevices in walls and bed cases, with particular attention paid to the corners of bednets and mattresses, should be performed. Speck-like masses of blood containing dung may be found behind wallpaper and at other sites when there is a heavy infestation. Bedbugs are extremely difficult to eradicate, and pest control is complicated due to insecticide resistance, lack of effective products, and health concerns about spraying mattresses with pesticides [22]. Nonchemical methods include vacuuming and heat or steam treatments.

So far, one case has been described where feral pigeons were the source of a bedbug infestation. The parasites invaded human habitations from an attic where feral pigeons lived and caused an unknown number of infestations in humans [28].

Pigeon bugs deriving from feral pigeons on the other hand caused several infestations in Hamburg [Udo Sellenschlo, pers. commun.]. Prisoners fed feral pigeons on the windowsills and were then bitten by pigeon bugs. In a second case pigeon bugs invaded a hotel from feral pigeons breeding in the courtyard. The bugs entered the room by funnels coming from outside that were only wallpapered. Several hotel guests and a female pest controller were bitten by the pigeon bugs.

The Pigeon Flea Ceratophyllus columbae

The original flea of the pigeon is the pigeon flea Ceratophyllus columbae, which is a frequent ectoparasite of feral pigeons (fig. 7). The male is approximately $2.5 \mathrm{~mm}$ long, the female $3.2 \mathrm{~mm}$. For a reliable identification, the form of the females' receptaculum seminis, the lengths of the bristles of the 8th sternite and the number of the barbs of the first breast ring can be used $[20,29]$.

In all known cases of pigeon flea infestations due to feral pigeons, the parasites invaded from pigeon nests [18]. In Ham- burg, Krall [30] found the parasite in 60\% of the inspected feral pigeon nests. Pigeon fleas are regularly found in the feral pigeon lofts of the 'Pigeon Action Basel' [3]. The spread of the fleas occurs actively by emigration or passively with pigeons. A large part of young pigeons leave their parents a few weeks after fledging and try to join another breeding colony [1]. Since pigeon fleas stick their eggs on the plumage of pigeons, the parasites can be passively distributed by emigrating pigeons. In cases of a heavy infestation, in one nest hundreds to thousands of pigeon fleas occur and can lead to the emigration of the bothered birds [31]. The lack of their natural host subsequently leads to the emigration of the fleas searching for new hosts. Larvae of the pigeon flea are able to starve for weeks, adults even for 11 months $[32,33]$. A flea infestation can therefore occur weeks or months after pigeons have been absent from the breeding sites.

Preferable bite sites of fleas are the extremities, face, neck, hips and shoulders. During the feeding which takes 2-6 min [34], the mouthparts pierce the host's skin to siphon blood, while saliva is secreted to prevent coagulation. Flea saliva is highly antigenic, producing pruritic papules often seen in clusters [35] and rarely hemorrhagic blisters.

Infestations with pigeon fleas may lead to important psychological stress [36]. Over a period of 2 months, a couple was repeatedly invaded by pigeon fleas. The source of the fleas was a single breeding pair of feral pigeons. The nest was located in the attic immediately above the couple's apartment, and the fleas entered along an unsealed heating pipe. The man noted on his hip vesicular skin lesions of $1 \mathrm{~mm}$ in diameter, surrounded by erythematous patches of approximately $1.5 \mathrm{~cm}$ in diameter. Almost every morning he found 8-10 new bite marks on each leg, typically ordered in lines each of 3 or 4 marks. At the bite sites, red indurated itching papules developed, surrounded by erythema that persisted for up to 2 weeks. Gradually, urticarial reactions to the bites developed in the form of wheals of approximately $1 \mathrm{~cm}$ in diameter, surrounded by erythema. With invasions repeated almost every night, the man gradually developed an allergic urticarial reaction. The patient suffered from generalized pruritus and on his arms and legs urticarial wheals appeared, which were not preceded by flea bites in these areas. Additionally, the patient expe- rienced intense itching at the sites of previous bites. The information of infestation by fleas resulted in phobia and insomnia. Despite the successful removal of the fleas and the pigeons, his parasitophobia persisted for 4 months.

To remove the source of infestation, nests and nest debris including the larvae have to be removed, the area formerly occupied by the pigeons has to be disinfested and a future access for the pigeons has to be prevented. Because pupal stages form about $10 \%$ of the flea population, disinfestation has to be repeated after 2 weeks to prevent a reinfestation with newly hatched imagos [34].

The Red Mite Dermanyssus gallinae

Dermanyssus gallinae (red mite, red poultry mite, chicken mite, fowl mite, roost mite) is the most common mite associated with feral pigeons and seems to be widely distributed in feral pigeon breeding sites (fig. 8). Red mites are able to starve for up to 8.5 months $[37,38]$ so that the parasite can emigrate from pigeon breeding sites a long time after their original hosts have disappeared. D. gallinae has 8 legs in adult and nymph stages, and moves rapidly with a speed of up to $120 \mathrm{~m} / \mathrm{h}$ [18]. This allows the mites to roam over large distances when searching for new hosts. The adult female is, depending on nutritional status, $0.75-1 \mathrm{~mm}$ long and $0.35-0.4$ $\mathrm{mm}$ wide and has stiletto-shaped chelicerae adapted for piercing and sucking that are retracted into the body during the resting state. The male is somewhat smaller with $0.6-0.7 \mathrm{~mm}$ length, and its chelicerae are scissor-shaped [39]. This bloodsucking mite is red to black in color when gorged with blood, and yellow-brown when unfed. It may infect a variety of birds worldwide including various domestic birds [40]. During the daytime it is usually hidden in the nesting material and in close proximity to the nest. Attacks on humans occur usually at night but infestations have also been reported during the daytime [41]. D. gallinae strikes rapidly and is able to bite in less than $1 \mathrm{~s}$ [42]. Cutaneous reactions in man are uncharacteristic and therefore difficult to diagnose. Usually, the mites cannot be found on the human host as they leave quickly after their blood meal. Clinical manifestations in humans include pruritic papules and occasionally vesicles, urticaria and erythema [42]. Stings are usually found on the trunk and limbs, but not in interdigital spaces, geni- 


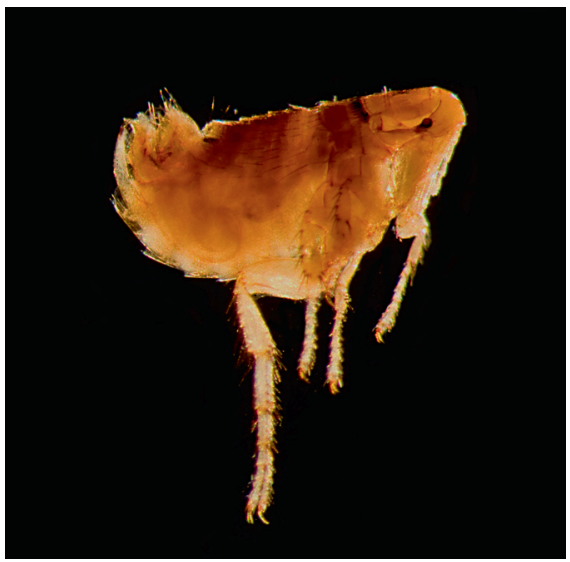

Fig. 7. The pigeon flea Ceratophyllus columbae is very similar to the widespread chicken flea Ceratophyllus gallinae.

tals or skin folds. The stings of red mites are irritating, but typically harmless.

For an infestation, the parasite has to cover the distance to the human host. There a two principal ways. In the first case the patient actively comes in contact with the source of infestation. All reported cases of such human activity leading to an infestation with feral pigeon parasites concerned the red mite D. gallinae. For example, Przybilla et al. [43] described a young woman who was stung by red mites when removing a feral pigeon nest from a toilet, and Baselga et al. [40] reported a case where a young woman brought a radio with red mites from the attic where feral pigeons lived. She and her brother were subsequently infested with the mites. One of us (Haag-Wackernagel) was attacked by hundreds of red mites shortly after a pigeon loft keeper had put a plastic bag with pigeon feces harboring the parasites in front of his office. In all other cases the parasite actively covered the distance to the human host from feral pigeon breeding or resting sites [18].

Auger et al. [42] reported a hospital infection in 10 patients by D. gallinae from feral pigeon nests on galleries, window ledges and air conditioners. The patients acquired the stings while walking in the galleries. Winkler [44] reported a hospital infection where D. gallinae entered the patients' rooms through ventilation openings and attacked 12 patients, one suffering over 500 bites. Cafiero et al. [45] reported several cases from Southern Italy

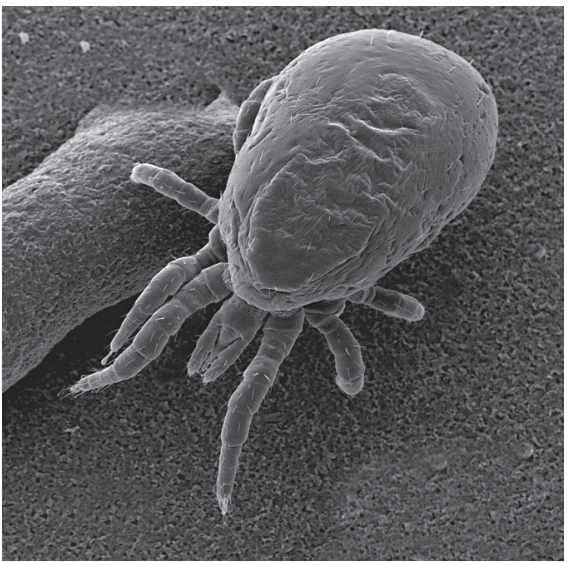

Fig. 8. The red mite Dermanyssus gallinae with its long legs is able to cover large distances when searching for new hosts.

where humans were attacked by red mites which all derived from abandoned feral pigeon nests. In Zurich (Switzerland) in 1930, many inhabitants panicked when an article in a local newspaper reported an outbreak of an infestation caused by the red blood mite. The feral pigeons were shot and the human population was advised not to feed pigeons as it was believed that even feeding pigeons might lead to infestations [46].

The parasite can be easily removed from the patient by showering or a full bath [47]. In most cases, medical treatment is not necessary. If treatment of mite bites is needed, antihistamines and mild topical corticosteroids typically bring rapid relief [48].

Elimination of the mite from the patient's environment is usually curative since they are only temporary visitors to the human skin and incapable of living and reproducing on the human host. Roaming mites in human living space can easily be removed with a vacuum cleaner or treated with a nontoxic insecticide spray as e.g. pyrethroids. Pigeon nests should be completely removed and treated with insecticides before disposal to prevent further infestations as the parasites may leave the waste bins. To prevent further nesting and roosting, access to buildings should be obstructed, and ledges and other structures should be protected with pigeon deterrent systems or structural restrictions $[49,50]$.

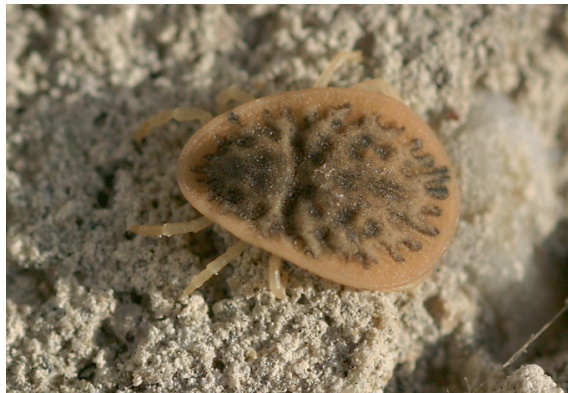

Fig. 9. The pigeon tick Argas reflexus represents the most significant health hazard posed by feral pigeons.
The Northern Fowl Mite

Ornithonyssus sylviarum

The northern fowl mite is a common, bloodsucking parasite that occurs on the plumage of the chicken in temperate regions throughout the world. It also affects pigeons and many wild birds [19]. The northern fowl mite is very similar to $D$. gallinae and therefore often confused with it [51]. The entire life cycle of Ornithonyssus sylviarum usually takes place on the host. Under high infestations the parasite can also be found in nest debris from where it can emigrate to human habitations. Up to date only 1 case has been reported where the mite emigrated from an abandoned feral pigeon nest together with $D$. gallinae and caused a nosocomial infection in a hospital [52].

\section{The Pigeon Tick Argas reflexus}

The most important ectoparasite, even the most significant health hazard posed by feral pigeons, is the soft tick $A$. reflexus (fig. 9). It is a temporary, bloodsucking ectoparasite of pigeons occurring in various parts of Europe, the Near East and the USA. This originally Mediterranean tick species was probably introduced to central Europe by humans together with the domestic pigeon [53]. A. reflexus is a widely present tick at breeding sites of feral pigeons and is harbored by most feral pigeon populations [54]. The tick is brownish, and unfed 4-15 $\mathrm{mm}$ long, 6-8 $\mathrm{mm}$ wide and 1-2 mm thick (fig. 9). Its typical habitat comprises pigeon nesting sites where the 
ticks seek shelter in crevices of walls or in slits in wood in the vicinity [55].

The main reasons for the ecological success of $A$. reflexus is its long life span of 7-10 years, according to Lüthgen [56] of even up to 18 years, and additional morphological, physiological and behavioral features help to save energy between the blood meals, which allows the ticks to starve for 6-10 years [53, 57, 58].

A. reflexus attacks its host during the night and remains hidden during the day. The host is recognized by contact chemoreceptors positioned on the pedipalps. Saliva is applied to the skin and the cheliceral digits cut into the skin of the host. After opening the host's skin, the mouthpart (capitulum), consisting of chelicera and hypostome, is inserted with sawing movements in a very quick process. The tick alternatively sucks and injects saliva. Ticks are pool feeders that take blood from a blood pool resulting from the laceration of blood vessels. All stages of $A$. reflexus including larvae may bite sleeping humans. Experiments of Kemper and Reichmuth [57] demonstrated that the pigeon tick is unable to lay eggs with only human blood meals and therefore not able to survive without its natural hosts.

In most cases only local manifestations occur. Normal bite reactions consist of itching, edema and erythema similar to mosquito bites [59]. In predisposed persons allergic symptoms occur within a few minutes after a bite. The allergens are presumably proteins of the saliva. Hilger et al. [60] were able to isolate the major pigeon tick allergen. People who have been bitten sometimes show symptoms of dizziness, headache, tachycardia, chills and sweating; even symptoms of an IgE-mediated anaphylactic shock including urticaria, shortness of breath and loss of consciousness have been reported. Buczek and Solarz [61] describe a fatal course due to anaphylactic shock in a 42-year-old man who died after 4 attacks by $A$. reflexus. The ticks invaded the apartment from a domestic pigeon loft that had been closed 3 years earlier. For the concerned patients pigeon tick infestation can mean a long time of suffering until the real cause has been diagnosed. Coudert et al. [62] report a patient who suffered 3 anaphylactic shocks within a 7-year period after pigeon tick bites. The ticks came probably from a feral pigeon's nest situated under a cornice.

Feral Pigeon Parasites
A case with far-reaching consequences has been reported by Tosti et al. [63] where a 34-year-old woman suffered from acute urticaria, associated with diffuse edema of the lips and eyelids, nausea, vomiting, abdominal pain and tinnitus after bites of $A$. reflexus which came from a feral pigeon nest in the loft. The patient developed a phobic obsessive neurosis, and following this reaction, she moved out of her apartment.

Three of 22 persons reported by Dautel et al. [55] showed severe symptoms following repeated pigeon tick bites. A considerable portion $(>40 \%)$ of people bitten by pigeon ticks develop hypersensitivity that causes local and systemic allergic reactions, and sensitization to pigeon tick bites can persist over 30 years without further re-exposures [64]. Bessot et al. [65] reported 12 cases of anaphylactic shock occurring after bites of pigeon ticks, in patients between 25 and 40 years old. The cases were characterized by sudden onset of mucocutaneous $(100 \%)$, respiratory $(67 \%)$, gastrointestinal (50\%) and cardiocirculatory symptoms (100\%), resulting in loss of consciousness $(67 \%)$ and requiring intensive care (67\%). Kleine-Tebbe et al. [66] reported 148 patients with $A$. reflexus bites of whom $8 \%$ showed anaphylactic systemic reactions.

Most case reports describe infestations with the pigeon tick due to breeding feral pigeons in buildings or on the building shell, but also infestations where the pigeons stayed near human habitations without a record of breeding having been reported [18]. Veraldi et al. [67] reported 2 very unusual cases where a woman who fed feral pigeons near her home and a man who was walking in a park were seemingly infested with pigeon ticks.

Hungry ticks only seem to attack man when the number of pigeons within reach has been greatly reduced or when they have been expelled from a breeding site [68]. In Berlin tick bites in humans occurred when the number of pigeons living in neglected lofts or attics of old houses was low in relation to the size of the local pigeon tick population, when pigeons were repelled from tick-infested locations or when tick-infested buildings were modernized without prior eradication of the ticks [54]. Ten of the 22 examined breeding locations (45\%) turned out to be infested with $A$. reflexus. Living ticks were present at all breeding sites with 50 or more feral pigeons [55]. In an attic where approxi- mately 100 adult pigeons had been living before, 23,640 nymphal and adult ticks were discovered [58]. Grzywinski [69] reported that ticks invaded a location through the wall from a neighboring house and infested 20 persons.

Patients with a local reaction to $A$. reflexus bites, e.g. itching, edema or erythema, need no medical treatment. If a hypersensitivity reaction is suspected, the patient must be admitted to hospital as soon as possible. Many cases demonstrate that only intensive medical care can prevent a dramatic course of an allergic reaction caused by $A$. reflexus bites [65, 70-72]. In the case of hypersensitivity reaction, the patient should be evacuated from his home until the living quarters are completely tick-free.

When the ticks lose their natural hosts, they preferably migrate into apartments because of the temperature difference between inner and outer rooms [68]. In each case where feral pigeons have been expelled from their breeding sites, a careful search for pigeon ticks at their hiding places should be performed. The pigeon tick is positively thigmotactic and needs direct body contact with its surroundings when hiding. Therefore A. reflexus prefers to hide in small and narrow hollow spaces. According to our experience a high detection rate is achieved when using a pocket lamp with a confined, variable focus. It is necessary to investigate all cracks, chinks and splices of walls and woodwork in the environment within at least $5 \mathrm{~m}$ around the former breeding site. Particularly attractive for pigeon ticks are lamp holders, presumably because of the high temperature. In places where no specimens were detected in lamp holders, no other hiding places of $A$. reflexus were found. Berlin health authorities recommend an inspection for the presence of $A$. reflexus in all buildings scheduled for redevelopment if they formerly harbored pigeons [53].

As an ad hoc measure, a glue barrier (double-sided adhesive tape) around beds and windowsills can prevent nocturnal bites. The source of infestations should be removed to prevent further invasions in human living space. Individual feral pigeon nests should be removed and access to breeding colonies should be obstructed. Subsequently the infested loci should be treated with insecticides. As all stages can starve for a long time, repeated treatment by specialized pest control companies is necessary [73]. 


\section{Discussion}

We describe a case where a female patient was concurrently attacked by 3 different ectoparasites deriving from feral pigeons. Pigeon ticks and red mites were determined by us, bedbugs by the patient. The symptoms of stings described by the patient are consistent with stings of bedbugs. She recognized the bedbugs by an internet search and from specimens of our collection, so her identification can be considered to be confirmed.

The patient and her partner suffered from hundreds of red mite stings simulating a generalized exanthema. It is well known that these mites infest humans by hundreds. A report [44] described a hospital infection with red mites where a patient suffered from 500 stings. The general symptoms described are difficult to interpret. Most likely it is an inflammatory response of the organism to foreign proteins.

In this case the cause of the dermatosis could only accidentally be diagnosed as a zoonosis due to feral pigeons. The ectoparasites of feral pigeons attack their human hosts preferably during the night and hide following their blood meal. Patients show nonspecific clinical signs that are very difficult to assign due to the problems of detection of the parasites and accurate identification of the species as well as relating the symptom to be due to a parasitization. Most dermatologists are aware of dermatoses associated with burrowing parasites as e.g. Sarcoptes scabiei, but if the dermatitis is caused by zoonotic ectoparasites it is often misdiagnosed. In the cases reported by Cafiero et al. [74], diagnoses were consistently generic and even when the eruption was attributed to acariasis, the possibility of zoonosis was not suspected. The patients often received symptomatic therapy, e.g. cortisone and tranquilizers, without a proper diagnosis. Additionally, none of the consulted physicians advised patients to inspect their homes for parasites.

Physicians should be aware of the possibility of an infestation with parasites deriving from feral pigeons. In cases with dermatosis of unclear etiology of patients living in urban areas, a zoonosis caused by feral pigeon ectoparasites should always be considered. Patients should be carefully interrogated to ask for feral pigeons close to their habitation, especially when they live in the uppermost apartment or directly under the roof. In the case of a suspicion, parasites can be caught for determination by a glue barrier that can be placed around the bed, e.g. with double-sided adhesive tape normally used to affix carpets. If the parasites are identified, a careful search in the living space of the patient, including house facade, balconies and ledges, ventilation openings, air conditioner inlets etc., should be performed [75]. Inside buildings particular electrical devices and other warm areas are preferred by pigeon parasites, as they are adapted to the pigeon's body temperature of $42^{\circ} \mathrm{C}$.

Ectoparasites are able to cover relatively large distances. Hence, adjoining houses and backyards have also to be considered as areas where feral pigeons could live as a source for ectoparasites. Even feral pigeons that only stay temporarily in an area can be a source of a parasitic infestation. Williams [76] reported a case where feral pigeons congregated to drink from small pools on an uneven flat roof where water accumulated following rain. Red mites emigrated from the pigeons and invaded an apartment where 2 women were infested.

If the source is localized, the whole area has to be disinfested by a pest controller. To prevent feral pigeons from further using a building, bird proofing by appropriate deterrent systems or architectural measures has to be carried out $[49,50]$.

A first measure often applied is the aspiration of the parasites with a vacuum cleaner. As shown in figure 1 engorged ticks do not survive aspiration because of bursting whereas starving ticks remain sound and could be able to leave the vacuum cleaner and could lead to reinfestation. Survival of aspiration and leaving the vacuum cleaner is known from bedbugs, whereas red mites are too delicate to resist. Aspiration of parasites without immediate disinfestation or safe disposal of the content of the cleaner bag bears the risk of reinfestation.

In cases where the source of an ectoparasite infestation is not detectable and reinfestations occur, the patients have to leave their habitation as an ultimate measure. This has to be recommended when recurrent anaphylactic reactions due to pigeon tick infestations occur. Miadonna et al. [77] described a case where a patient changed his residence after having developed an anaphylactic shock consisting of dyspnea and hypotension due to pigeon tick bites.

Till now more than 370 infestations of humans due to feral pigeons have been re- ported. In $71 \%$ of these cases, the sources of infestations were nests on the building shell or inside buildings [18]. In the present case, the pigeons used a balcony after having been attracted by food provided by the former tenant. To support a population of ectoparasites, a continuous supply of hosts must be guaranteed. Buildings infested with feral pigeons for longer than 1 year [78] or breeding sites populated with more than 50 feral pigeons [55] are at high risk of harboring pigeon ticks. Hence, it is surprising that only few pigeons using a small balcony were the source of infestations with 3 parasite species. To our knowledge only 1 case has been reported where more than 1 parasite species were transmitted from feral pigeons to humans. Vargo et al. [52] described a hospital infection with 2 mite species, D. gallinae and O. sylviarum, which originated from an abandoned pigeon nest.

Even a single abandoned feral pigeon nest can be the cause for the emigration of ectoparasites and infestation of humans as demonstrated for red mites [41] and pigeon fleas [36]. From domestic pigeons it is known that the birds leave their breeding sites when parasite populations are very high [31]. Such emigrating individuals transport parasites to new places. Emigrating young birds occupying new breeding sites additionally play an important role in the dissemination of parasites.

Feral pigeon colonies close to human habitations bear a latent risk of parasitic infestations and are difficult to prevent. The real cause of the problem is the high feral pigeon populations in our cities due to a large food basis provided deliberately by pigeon feeding or accidentally by discarded food. Infestations of humans with feral pigeon parasites are therefore only one side of the problem linked with the overpopulation by these birds in our cities. Sustainable solutions can only be reached by integrative measures as e.g. public education and feeding restrictions [3].

\section{Dedication}

We dedicate this article to the late Prof. Dr. Theo Rufli, the former director of the Dermatology Clinic of the University of Basel, an enthusiastic and knowledgeable dermatological entomologist. 


\section{References}

1 Johnston RF, Janiga M: Feral Pigeons. Oxford, Oxford University Press, 1995.

2 Vater G: Wie viele Tauben gibt es in mitteleuropäischen Städten? Prakt Schädlingsbekämpfer 1998;50:12-17.

3 Haag-Wackernagel D: Street pigeons in Basel. Nature 1993;361:200.

4 Haag-Wackernagel D: Regulation of the street pigeon in Basel. Wildlife Soc Bull 1995; 23:256-260.

5 Baldaccini NE, Mongini E, Ragionieri L: Die Tauben in Bozen: Kontrollmethode und Bevölkerungsdynamik. 3. Internationale Tagung Infektionskrankheiten in den $\mathrm{Al}$ penländern, Seis am Schlern, 1994, pp 4950.

6 Kösters J, Kaleta E, Monreal G, Siegmann O: Das Problem der Stadttauben. Dtsch Tierärztebl 1991;4:272-276.

7 Bassi M, Chiatante D: The role of pigeon excrement in stone biodeterioration. Int Biodeterioration Bull 1976;12:73-79.

8 Mendez-Tovar LJ, Mainou LM, Pizarro SA, Fortoul-Vandergoes T, Lopez-Martinez R: Fungal biodeterioration of colonial facades in Mexico City. Rev Mex Micol 1995;11:133144.

9 Zucconi S, Galavotti S, Deserti R: I colombi in ambiente urbano. Sintesi del progetto di ricerca Nomisma. Ig Alim Disinfest Ig Ambient nov/dic 2003, pp 9-22.

10 Pimentel D, Zuniga R, Morrison D: Update on the environmental and economic costs associated with alien-invasive species in the United States. Ecol Econ 2005;52:273-288.

11 Haag-Wackernagel D, Moch H: Health hazards posed by feral pigeons. J Infect 2004;48: 307-313.

12 Haag-Wackernagel D: Human diseases caused by feral pigeons. Adv Verteb Pest Manag 2006;4:31-58.

13 Gatti M, Di Silverio A, Cespa M, Mosca M: Primary unusual cutaneous cryptococcosis in an HIV former drug abuser patient. Mycosis 1997;40:101-102.

- 14 Calvert JE, Baldwin CI, Allen A, Todd A, Bourke SJ: Pigeon fanciers' lung: a complex disease? Clin Exp Allergy 1999;29:166-175.

15 du Marchie Sarvaas GJ, Merkus PJ, de Jongste JC: A family with extrinsic allergic alveolitis caused by wild city pigeons: a case report. Pediatrics 2000;105:E62.

16 Bahna SL: A custodian cured the doctor! Pediatrics 2000;105:E71.

-17 Curtis L, Lee BS, Cai D, Morozova I, Fan JL, Scheff P, Persky V, Einoder C, Diblee S: Pigeon allergens in indoor environments: a preliminary study. Allergy 2002;57:627631.

18 Haag-Wackernagel D: Gesundheitsgefährdungen durch die Strassentaube Columba livia: Parasiten. Amtstierärztl Dienst Lebensmittelkont 2008;3:174-188.

19 Flynn RJ: Parasites of Laboratory Animals. Ames, Iowa State University Press, 1973.
20 Weidner $\mathrm{H}$, Sellenschlo U: Vorratsschädlinge und Hausungeziefer. Heidelberg, Spektrum Akademischer Verlag, 2003, p 251S.

21 Usinger RL: Monograph of Cimicidae. The Thomas Say Foundation, Entomological Society of America, Baltimore, 1966, Vol. VII.

-22 Goddard J, de Shazo R: Bedbugs (Cimex lectularius) and clinical consequences of their bites. JAMA 2009;301:1358-1366.

23 Stutt AD, Siva-Jothy MT: Traumatic insemination and sexual conflict in the bedbug $\mathrm{Ci}$ mex lectularius. Proc Natl Acad Sci USA 2001;98:5683-5687.

24 Thomas I, Kihiczak GG, Schwartz RA: Bedbug bites: a review. Int J Dermatol 2004;43: 430-433.

25 Stucki A, Ludwig R: Images in clinical medicine: bedbug bites. N Engl J Med 2008;359: 1047.

26 Reinhardt K, Kempke D, Naylor RA, SivaJothy MT: Sensitivity to bites by the bedbug, Cimex lectularius. Med Vet Entomol 2009; 23:163-166.

27 Liebold K, Schliemann-Willers S, Wollina U: Disseminated bullous eruption with systemic reaction caused by Cimex lectularius. J Eur Acad Dermatol Venereol 2003;17:461-463.

28 Frickhinger H: Die Gefahr der wilden Tauben. Anz Schädlingskd 1937;13:66.

29 Peus F: Die Flöhe. Hygienische Zoologie. Leipzig, Verlag Dr. P. Schöps, 1938, vol 5.

30 Krall S: Oekofaunistische Untersuchungen der Insekten in Nestern der Stadttaube (Columba livia domestica L.) unter besonderer Berücksichtigung schädlicher und lästiger Arten. Entomol Mitt Zool Mus Hamburg 1981;7:29-44.

31 Vogel K, Lüthgen W, Müller H, Schrag L, Vogel M: Taubenkrankheiten. Berlin, VEB Deutscher Landwirtschaftsverlag, 1983, p 460 S.

32 Vogel K: Taubenkrankheiten. Berlin, VEB Deutscher Landwirtschaftsverlag, 1965.

33 Wolff K: Vogelflöhe als fakultative Ektoparasiten des Menschen. Schweiz Rundsch Med 1975;64:1173-1175.

34 Beck W, Clark HH: Differentialdiagnose medizinisch relevanter Flohspezies und ihre Bedeutung in der Dermatologie. Hautarzt 1997;48:714-719.

35 Stibich AS, Carbonaro PA, Schwartz RA: Insect bite reactions: an update. Dermatology 2001;202:193-197.

- 36 Haag-Wackernagel D, Spiewak R: Human infestation by pigeon fleas (Ceratophyllus columbae) from feral pigeons. Ann Agric Environ Med 2004;11:1-4.

37 Kirkwood A: Longevity of the mites Dermanyssus gallinae and Liponyssus sylviarum. Exp Parasitol 1963;14:358-366.

38 Beck W: Landwirtschaftliche Nutztiere als Vektoren von parasitären Epizoonoseerregern und zoophilen Dermatophyten. Hautarzt 1999;50:621-628.
39 Schweizer J: Die Landmilben der Schweiz, Parasitiformes. Denkschr Schweiz Naturforsch Ges 1961;84:155-156.

40 Baselga E, Drolet BA, Esterly NB: Avian mite dermatitis. Pediatrics 1996;97:743-745.

41 Haag D: Brütende Strassentauben als Ursache einer Invasion von Dermanyssus gallinae (De Geer, 1778). Prakt Schädlingsbekämpfer 1988;8:180.

42 Auger P, Nantel J, Meunier N, Harrsion RJ, Loiselle R, Gyorkos TW: Skin acariasis caused by Dermanyssus gallinae (de Geer): an in-hospital outbreak. Can Med Assoc J 1979;120:700-703.

43 Przybilla B, Ryckmanns F, Postner M, Klovekorn W: Epizootic disease caused by the mite Dermanyssus gallinae (De Geer 1778). Hautarzt 1983;34:335-338.

44 Winkler A: Endemie durch Vogelmilben (Dermanyssus gallinae) in einem Krankenhaus. Dermatol Wochenschr 1967;16:458459.

45 Cafiero MA, Circella E, Santagada G, Parisi A, Lomuto M, Camarda A: Infestatione da Dermanyssus gallinae nell'uomo. Un problema di igiene urbana. Obiett Doc Vet 2007; 6:41-45.

46 Schrafl A: Taubenkrätze. Schweiz Med Wochenschr 1930;38:900.

47 Döhring E: Zur Lebensweise und Bekämpfung von Vogelmilben und einigen anderen Ektoparasiten in Geflügelställen. Prakt Schädlingsbekämpfer 1970;2:13-20.

48 Orton DI, Warren LJ, Wilkinson JD: Avian mite dermatitis. Clin Exp Dermatol 2000;25: 129-131.

49 Haag-Wackernagel D: Behavioural responses of the feral pigeon (Columbidae) to deterring systems. Folia Zool 2000;49:25-39.

50 Haag-Wackernagel D, Geigenfeind I: Protecting buildings against feral pigeons. Eur J Wildlife Res 2008;54:715-721.

51 Beck W, Pantchev N: Praktische Parasitologie bei Heimtieren. Kleinsäuger - Vögel Reptilien - Bienen. Hannover, Schlütersche Verlagsgesellschaft, 2006, p 318S.

52 Vargo JA, Ginsberg MM, Mizrahi M: Human infestation by the pigeon mite: a case report. Am J Infect Control 1983;11:24-25.

53 Dautel H, Scheurer S, Kahl O: The pigeon tick (Argas reflexus): its biology, ecology, and epidemiological aspects. Zentralbl Bakteriol 1999;289:745-753.

54 Scheurer S, Dautel H: Verbreitung und Bekämpfung von Argas reflexus (Fabr) (Acarai, Argasidae) in Berlin. Mitt Dtsch Ges Allg Angew Entomol 1994;9:171-174.

55 Dautel H, Kahl O, Knülle W: The soft tick Argas reflexus in urban environments and its medical significance in Berlin (West). J Appl Entomol 1991;111:380-390.

56 Lüthgen W: Taubenkrankheiten. Reutlingen, Oertel \& Spörer Verlags-GmbH, 2006. 
57 Kemper H, Reichmuth W: Die Taubenzecke als Parasit des Menschen. Z Angew Entomol 1941;28:507-518.

58 Mayer E: Parasitologische Untersuchungen an Taubenbeständen in Berlin; Inauguraldissertation, Institut für Parasitologie der Veterinär-Medizinischen Fakultät der Freien Universität Berlin, 1954, vol 118, pp 133.

59 Bircher AJ: Systemic immediate allergic reactions to arthropod stings and bites. Dermatology 2005;210:119-127.

-60 Hilger C, Bessot JC, Hutt N, Grigioni F, De Blay F, Pauli G, Hentges F: IgE-mediated anaphylaxis caused by bites of the pigeon tick Argas reflexus: cloning and expression of the major allergen Arg r 1. J Allergy Clin Immunol 2005; 115:617-622.

61 Buczek A, Solarz K: Attacks on people by Argas reflexus (Ixodida, Argasidae) - harmful parasites for humans and animals. Polski Tygodnik Lekarski 1993;48:238-239.

62 Coudert J, Battesti MR, Despeignes J: Un cas d'allergie aux piqûres d'Argas reflexus. Bull Soc Pathol Exot 1972;65:884-889.

- 63 Tosti A, Peluso AM, Spedicato S: Urticaria - angioedema syndrome caused by an $\mathrm{Ar}$ gas reflexus sting. Contact Dermatitis 1988; 19:315-316.

64 Spiewak R, Lundberg M, Johansson G, Buczek A: Allergy to pigeon tick (Argas reflexus) in Upper Silesia, Poland. Ann Agric Environ Med 2006;13:107-112.
65 Bessot JC, Kopferschmitt MC, de Blay F, Dietemann A, Nirrengarten A, Hutt N, Le Coz C, Bouzouba A, Sainte Laudy J, Pauli G: Choc anaphylactique après morsure de tiques de pigeon (Argas reflexus): à propos de douze cas. Rev Fr Allergol Immunol Clin 1997;37:431-437.

66 Kleine-Tebbe J, Heinatz A, Gräser I, Dautel H, Nordskov I, Hansen G, Kespohl S, Rihs HP, Raulf-Heimsoth M, Vater G, Rytter M, Haustein UF: Bites of the European pigeon tick (Argas reflexus): risk of IgE-mediated allergic sensitizations and severe analphylactic reactions. J Allergy Clin Immunol 2006;117: 190-195.

67 Veraldi S, Barbareschi M, Zerboni R, Scarabelli G: Skin manifestations caused by pigeon ticks (Argas reflexus). Cutis 1998;61: 38-40.

68 Genchi C, Falagiani P: Allergische Reaktionen nach Argasiden-Biss: eine zunehmende Gefahr für die Volksgesundheit. Proc Infectious Diseases in Alpine Areas, Castelrotto-Siusi, 1991, pp 37-38.

69 Grzywinski L: Omwazja Argas reflexus u Ludzi. Wiadomosci parazytologiczne 1970;XVI:457-461.

70 Sirianni MC, Mattiacci G, Barbone B, Mari A, Aiuti F, Kleine-Tebbe J: Anaphylaxis after Argas reflexus bite. Allergy 2000;55:303.

71 Quercia O, Emiliani F, Foschi FG, Stefanini GF: Anaphylactic shock to Argas reflexus bite. Eur Ann Allergy Clin Immunol 2005; $37: 66-68$.
72 Spiewak R, Szostak W, Kubicka K, Ciura D, Lundberg M, Hohansson SGO, Buczek A: An 'endemic' allergy to pigeon ticks (Argas reflexus) after removal of dovecotes. 23rd EAACI Congress, Amsterdam, 2004, Allergy Forum 5: In vitro diagnosis in allergy: laboratory tests between facts and fiction, p 157.

73 Herrmann J: Taubenzeckenbekämpfung. Umweltmedizinischer Informationsdienst 2000;3:21-24 (http://umweltbundesamt.de).

74 Cafiero MA, Camarda A, Circella E, Galante D, Lomuto M: An urban outbreak of red mite dermatitis in Italy. Int J Dermatol 2009;48: 1119-1121.

75 Haag-Wackernagel D: Parasites from feral pigeons as a health hazard for humans. Ann Appl Biol 2005;147:203-210.

76 Williams RW: An infestation of a human habitation by Dermanyssus gallinae (De Geer, 1778) (Acarina: Dermanyssidae) in New York City resulting in sanguisugent attacks upon the occupants. Am J Trop Med Hyg 1958;7:627-629.

-77 Miadonna A, Tedeschi A, Leggieri E, Falagiani P, Nazzari M, Manzoni M, Zanussi C: Anaphylactic shock caused by allergy to the venom of Argas reflexus. Ann Allergy 1982; 49:293-294.

78 Vater A, Vater G: Zecken kontra Wohnbedarf - Sanierung kontra Zecken. Leipziger Bauführer, Stadtlandschaften und gesundes Wohnen, 1995, pp 72-75. 